Understanding and addressing unequal career opportunities in the 'new career' era: an analysis of the role of structural career boundaries and organizational career management

Peer-reviewed author version

VAN LAER, Koen; Verbruggen, Marijke \& Janssens, Maddy (2019) Understanding and addressing unequal career opportunities in the 'new career' era: an analysis of the role of structural career boundaries and organizational career management. In: International journal of human resource management,.

DOI: $10.1080 / 09585192.2019 .1660700$

Handle: http://hdl.handle.net/1942/29571 


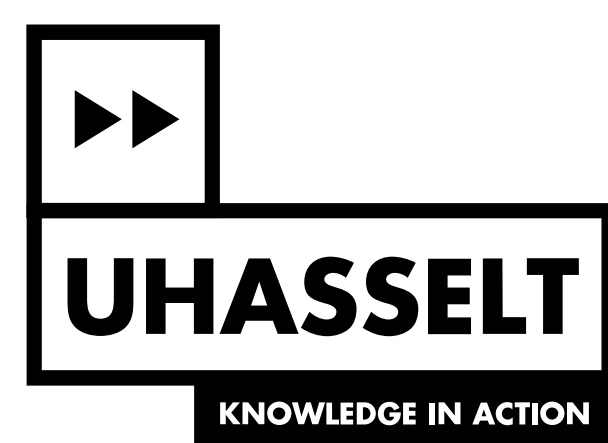

Understanding and addressing unequal career opportunities in the 'new career' era: an analysis of the role of structural career boundaries and organizational career management Link

Peer-reviewed author version

Made available by Hasselt University Library in Document Server@UHasselt

Reference (Published version):

Van Laer, Koen; Verbruggen, Marijke \& Janssens, Maddy(2019) Understanding and addressing unequal career opportunities in the 'new career' era: an analysis of the role of structural career boundaries and organizational career management. In: International journal of human resource management,

DOI: 10.1080/09585192.2019.1660700

Handle: http://hdl.handle.net/1942/29571 


\title{
Understanding and addressing unequal career opportunities in the 'new career' era: An analysis of the role of structural career boundaries and organizational career management
}

\author{
Koen Van Laer ${ }^{\mathrm{a}}$, Marijke Verbruggen ${ }^{\mathrm{b}}$, Maddy Janssens ${ }^{\mathrm{b}}$ \\ ${ }^{a}$ SEIN, Faculty of Business Economics, Hasselt University, Belgium \\ ${ }^{b}$ Department of Work and Organisation Studies, Faculty of Economics and Business, \\ KU Leuven, Belgium
}

Accepted for publication in The International Journal of Human Resource Management

By bringing together the literature on 'new careers', career boundaries and organizational career management (OCM), on different social identity groups, and on diversity management, this article aims to contribute to debates on unequal career opportunities and career boundaries in the 'new career' era. First, it develops propositions on the way structural career boundaries involving qualifications and labour market scripts contribute to unequal opportunities to share in the promises of the 'new career' discourse. We specifically argue that these boundaries affect the careers of different social identity groups to different degrees because common sense views of 'ideal' qualifications and 'ideal' labour market scripts are infused with social identities. Second, this article develops propositions on the way different types of OCM practices address career boundaries and whether they can contribute to equal opportunities. We argue that traditional OCM practices will only result in equal opportunities if common sense views of 'ideal' qualifications and 'ideal' labour market scripts are changed. Finally, we propose that incorporating inclusive common sense views of qualifications and labour market scripts in bundles of OCM practices enables these to effectively contribute to equal career opportunities.

Keywords: New careers; career boundaries; social identities; organizational career management; inequality; diversity; boundaryless and protean careers 


\section{Introduction}

For the last two decades, debates on careers have been strongly shaped by the "new career' discourse, which promises that a shift towards self-directed careers characterized by flexibility and labour market mobility gives individuals more freedom to attain both objective and subjective career success (Arthur, 2014; Arthur \& Rousseau, 1996; Hall, 1996, 2004). However, career scholars (e.g. Arnold \& Cohen, 2008; Inkson, Gunz, Ganesh, \& Roper 2012; Sullivan \& Baruch, 2009) have increasingly warned that individuals with specific social identities, such as women, ethnic or racial minorities, disabled people, and older individuals, do not have equal opportunities to share in these promises. This inequality in the 'new career' era has stimulated renewed attention for career boundaries. While much attention has gone to boundaries linked to individual characteristics, some career studies (e.g. Dany, Louvel, \& Valette, 2011; Garbe \& Duberley, 2019; Iellatchitch, Mayrhofer, \& Meyer, 2003; Ituma \& Simpson, 2009; Gunz, Peiperl, \& Tzabbar, 2007) have drawn attention to structural career boundaries, involving common sense views that are engrained in labour market conventions, practices, policies and institutions. However, these debates offer little analysis of why or how structural boundaries might contribute to the unequal career opportunities of different social identity groups.

The goal of this paper is to advance debates on unequal opportunities and career boundaries in the 'new career' era by exposing how structural career boundaries are infused with social identities and by exploring the way Organizational Career Management $(\mathrm{OCM})$ practices address career boundaries and can contribute to equal opportunities. First, answering calls for continued investigations of career boundaries (e.g. Arnold \& Cohen, 2008; Inkson et al., 2012), this article develops propositions on 
Van Laer, Verbruggen \& Janssens

the way two types of structural career boundaries whose continued existence is particularly stressed in the career literature on structural boundaries, those involving qualifications and labour market scripts, are infused with social identities and contribute to unequal career opportunities. Second, answering calls for continued attention for the role of organizations in individuals' career development (e.g. De Vos \& Cambré, 2017; Garbe \& Duberley, 2019), this article develops propositions on the way different types of OCM practices address career boundaries and whether they can contribute to equal opportunities. Finally, we propose that incorporating inclusive common sense views of qualifications and labour market scripts in bundles of OCM practices enables these to effectively contribute to equal career opportunities. Answering calls for more interdisciplinary debates on 'new careers' (e.g. Arnold \& Cohen, 2008; Arthur, 2014; Inkson et al., 2012; Garbe \& Duberley, 2019), this study develops these propositions by adopting a critical diversity perspective (Zanoni, Janssens, Benschop, \& Nkomo, 2010), and drawing on the literature on different social identities and diversity management. Before developing these propositions, we introduce current debates on boundaries in the 'new career' literature.

\section{Career success and career boundaries}

The 'new career' discourse and its most prominent career models - the boundaryless and the protean career model - offer an optimistic view of careers on the contemporary labour market. It promises that the decline of 'traditional' careers characterized by longterm employment in the same organization will provide new freedoms and opportunities for individuals to shape their own careers and attain both subjective (e.g. job or career satisfaction) and objective career success (e.g. salary or promotions) (Arthur, 2014; Arthur \& Rousseau, 1996; Hall, 1996, 2004). However, an increasing group of career scholars argue that opportunities for freedom and success might be hampered by the 
Van Laer, Verbruggen \& Janssens

continued impact of career boundaries.

In the career literature, boundaries have predominantly been conceptualized as involving individual characteristics, of either 'career owners or those with whom they interact' (Gunz et al., 2007, p. 477), that constrain people's careers. The former refer to career actors' own characteristics that prevent them from making the most of the freedoms offered to them in the 'new career' era. Examples are low self-efficacy, riskaversion, or a lack of human capital (Baruch \& Vardi, 2016; Sullivan \& Baruch, 2009). The latter refer to impediments to career success resulting from other labour market actors' individual characteristics or behaviours. Examples are gatekeepers' psychological processes and individual preferences for, or personal biases against, certain career actors (Baruch \& Vardi, 2016; Gunz et al., 2007).

Another, though less common, conceptualization of career boundaries moves beyond the individual level, and approaches career boundaries as structural level phenomena. From this perspective, boundaries do not simply involve individual characteristics or individually held beliefs, but rather 'common sense views', i.e., assumptions that are 'shared by enough actors for a macro-level pattern to become apparent' (Gunz et al., 2007, p. 477) and that become engrained in labour market conventions, practices, policies and institutions. Existing studies particularly stress the continued existence of two types of structural career boundaries: structural boundaries involving qualifications (e.g. Iellatchitch et al., 2003; Ituma \& Simpson, 2009; Gunz et al., 2007) and structural boundaries involving labour market scripts (e.g. Dany et al., 2011; Garbe \& Duberley, 2019; Laudel, Bielick, \& Gläser, 2019). The first type refers to common sense views of the qualifications required to make particular career moves and attain career success. These do not merely involve knowledge that is objectively required to perform a particular job, but also the socially shared views on, for example, 
Van Laer, Verbruggen \& Janssens

the value of different degrees or prior work experience, which can become embedded in selection processes (Iellatchitch et al., 2003; Ituma \& Simpson, 2009; Gunz et al., 2007). The second commonly identified type of structural boundaries, those involving labour market scripts, capture common sense views of the behaviour 'that needs to be done in order to succeed' (Dany et al., 2011: 992). Examples are views on appropriate professional and career behaviour, such as being internationally mobile or making frequent career moves, which can become embedded in evaluation and promotion processes (Dany et al., 2011; Garbe \& Duberley, 2019; Iellatchitch et al., 2003; Ituma \& Simpson, 2009; Laudel et al., 2019).

While explorations of structural career boundaries have complemented analyses that focus more strongly on the individual level, they do not sufficiently address one problem that career scholars are pointing to (e.g. Arnold \& Cohen, 2008; Inkson et al., 2012; Sullivan \& Baruch, 2009): that individuals with particular social identities, such as women, ethnic or racial minorities, disabled people, and older individuals have less opportunities to share in the promises of the 'new career' discourse. Specifically, these discussions seem to imply that these structural boundaries affect all social identity groups equally. They do so by either overlooking the issue of social identities, or identifying separate structural boundaries related to specific social identities. For example, Ituma and Simpson (2009) identify the structural boundary 'ingrained in the Nigerian psyche' (p. 748) to hire individuals from the same ethnic group as a separate boundary next to other structural career boundaries. In this way, debates on structural career boundaries risk obscuring how also commonly identified, seemingly identityneutral, structural career boundaries might disproportionally affect specific social identity groups. 
Van Laer, Verbruggen \& Janssens

This oversight is problematic because it causes debates on careers to overlook an important source of inequality in the 'new career' era. This, in turn, prevents us from evaluating whether and how OCM practices, through which organizations continue to impact the career development of employees (Baruch, 2003; Baruch \& Peiperl, 2000), can contribute to ensuring that individuals from all social identity groups can equally enjoy the promises of the 'new career' discourse. To address this gap, we first develop propositions on the infusion of structural career boundaries with social identities. Then, we will analyse whether and how OCM practices address career boundaries.

\section{The infusion of structural career boundaries with social identities}

A first goal of this article is to contribute to theoretical debates on career boundaries by developing propositions on the way structural career boundaries are infused with social identities and therefore affect different social identity groups differently. We specifically develop propositions on the infusion with social identities of the two types of structural career boundaries whose continued existence is particularly stressed in the career literature on structural boundaries (e.g. Dany et al., 2011; Garbe \& Duberley, 2019; Gunz et al., 2007; Laudel et al., 2019): structural career boundaries involving qualifications and structural career boundaries involving labour market scripts. Reflecting calls for more interdisciplinary debates on 'new careers' (e.g. Arnold \& Cohen, 2008; Arthur, 2014; Garbe \& Duberley, 2019; Inkson et al., 2012), we develop these propositions drawing on a critical diversity perspective (Zanoni et al., 2010). This perspective focuses on the connection between labour market structures and relations of power between social identity groups, and is therefore ideally suited to analyse the role of social identities in these boundaries. Drawing on the streams of literature on four social identities (gender, race/ethnicity, disability and age) commonly linked to potential difficulties in reaping the advantages of the 'new career' discourse, we 
Van Laer, Verbruggen \& Janssens

develop four propositions that offer a novel understanding of the infusion of structural career boundaries with social identities. At the end of this section, we provide a table that gives an overview of the connections between common sense views and arguments in the literature on different social identities.

\section{Social identities and structural career boundaries involving qualifications}

We propose that structural career boundaries involving qualifications are infused with social identities in two related yet distinct ways: through the infusion with social identities of common sense views of 'ideal' competencies and of 'ideal' job holders.

First, structural career boundaries involving qualifications are infused with social identities as social identities influence the (ascribed) attributes that become recognized as valuable competencies and the way these competencies are to be performed. This turns certain social identity groups into the standard for 'ideal' competencies. Most evidence of this connection between competencies and social identities can be found in the literature on the 'gendered nature' of skills. It argues that common sense view of 'ideal' competencies are defined around men, which affects both the attributes that become recognized as competencies and the valuation of these competencies. Specifically, it is argued that the attributes stereotypically ascribed to men, such as strength, decisiveness, competitiveness, or technological expertise, become more readily constructed as competencies than the attributes commonsensically associated with women, such as dexterity, empathy, caring or collaborating. Moreover, even if these latter are recognized as competencies, they are not valued as highly as ‘male’ competencies (Ely \& Meyerson, 2010; Peterson, 2007; Roos \& Zanoni, 2016). This means that men are more likely than women believed to possess valuable competencies. Furthermore, this literature shows that while adopting 'feminine' competencies to complement their 'ideal' competencies is associated with more career 
success for men, women who acquire 'ideal' 'male' competencies are often not afforded the same career rewards as men. For example, studies on 'female' leadership show that this form of leadership continues to be valued less than 'ideal' (masculine) leadership, and that men more than women can advance their careers by 'learning' the leadership skills associated with the opposite gender (Peterson, 2007; Roos \& Zanoni, 2016).

The literature on other social identities provides further evidence to support our proposition on the infusion with social identities of 'ideal' competencies. Research on disability discusses the infusion of common sense views of 'ideal' competencies with ableism, causing them to reflect able-bodied individuals. Examples of this are the requirement to have a driving license when this is not essential for the job performance, or the use of non-disabled individuals' activities (e.g. being a member of a sport club) as proxies for 'ideal' soft skills (Foster \& Wass, 2013; Lindsay et al., 2014; McKinney \& Swartz, 2019). Meanwhile studies on age show that the attributes that are recognized in the 'new career' era as 'ideal' career competencies, such as proactivity, entrepreneurism, and a willingness to learn, are those traditionally ascribed to young individuals. By contrast, attributes linked to older individuals, such as stability, conservatism, and risk aversion, are not recognized as competencies, or become seen as weaknesses (Riach \& Kelly, 2013; Thomas, Hardy, Cutcher, \& Ainsworth, 2014). As a result, younger individuals will be more likely to be believed to possess 'ideal' career competencies. Finally, research on ethnicity/race points to similar processes, for example highlighting the devaluation of non-Western degrees or training in comparison to 'ideal' Western degrees, and the use of the dominant racial or ethnic groups as the standard for 'ideal' soft skills, such as 'correct' customer and communication skills (Hakak \& Al Ariss, 2013; Moss \& Tilly, 1996). This leads us to the following proposition: 
Van Laer, Verbruggen \& Janssens

Proposition 1: Career boundaries involving qualifications affect the career success of different social identity groups to different degrees because common sense views of 'ideal' competencies are infused with social identities.

Second, we propose that structural career boundaries involving qualifications are infused with social identities as social identities influence common sense views of the jobs or occupations (categories of jobs) for which individuals are considered qualified, thereby turning certain social identity groups into 'ideal' holders of certain jobs. Moreover, jobs become valued based on the status of the social identity group they are connected to, and designed around the ways of working of their 'ideal' job holder. Disability studies take the most radical approach to this topic by arguing that a common sense view exists that disabled individuals are not qualified for paid employment in the regular economy. This literature argues that this view finds its origins in the period of industrialization, when employers started to look for 'average' bodies to employ in standardized jobs. This led to the common sense view that only non-disabled individuals are qualified to hold 'regular' jobs and to the design of jobs around the ways of working of non-disabled people. By contrast, disabled individuals have become mainly seen as 'ideal' job holders for positions outside of the regular economy, which are associated with little objective career success (Barnes \& Mercer, 2005; Foster \& Wass, 2013).

Studies on other social identities rather argue that different social identity groups are seen as 'ideal' holders of different jobs in the regular economy. Studies on age highlight the common sense view that older individuals are 'ideal' job holders for 'mature' occupations (e.g. banking). By contrast, they are less likely to be seen as an 'ideal' holder of jobs that aim to adopt and project a 'modern' and 'dynamic' image, 
Van Laer, Verbruggen \& Janssens

such as most jobs in the 'new economy' (e.g. in the IT sector). Studies further show that older employees can experience problems to perform in jobs designed around 'young' ways of working (Riach \& Kelly, 2013; Thomas et al., 2014; Truxillo, Cadiz, \& Hammer, 2015). Gender studies show that men rather than women continue to be seen as the 'ideal' holder of jobs connected to the highest levels objective career success, while women are more likely to be considered qualified for lower-status 'feminized' jobs (e.g. supportive and administrative functions) (Acker, 2006; Kaufman, 2002). Studies on race and ethnicity similarly highlight the existence of the common sense view of subordinate racial and ethnic groups as 'ideal' holders of jobs that are connected to little career success. This involves for example 'migrant' or 'brown-collar' jobs, which are not desired by dominant groups because they offer little objective career success, and jobs that specifically cater to similar ethnic or racial client groups. Moreover, like studies on other social identities, they show that when individuals from subordinate ethnic or racial groups become employed in high-status jobs, they often have to invest much time overcoming the common sense view that they are not as qualified as 'ideal' job holders (Acker, 2006; Kaufman, 2002). Together, this leads us to the following proposition:

Proposition 2: Career boundaries involving qualifications affect the career success of different social identity groups to different degrees because common sense views of 'ideal' job holders are infused with social identities.

\section{Social identities and structural career boundaries involving labour market scripts}

We propose that structural career boundaries involving labour market scripts are infused with social identities through the infusion with social identities of common sense views of 'ideal' careers and of 'ideal' workplace conduct. 
First, structural career boundaries involving labour market scripts are infused with social identities as social identities are engrained in the career trajectories and characteristics that become recognized as important to attain career success, thereby turning certain social identity groups into the standard for 'ideal' careers. This process has mainly been studied in the gender literature, which has long argued that common sense views of 'ideal' careers reflect a 'male breadwinner model' and involve careers that can be pursued without the interference of domestic or family obligations, and that are characterized by uninterrupted, full-time availability. Given the continued imbalance in domestic labour, women, and especially working mothers, are often less able to, or believed by employers to be less willing to, follow these 'ideal' careers. While it is possible for women to deviate from these 'ideal' careers, studies have shown that doing so endangers future career opportunities (Acker, 2006; Kossek, Lewis, \& Hammer, 2010; Mainiero \& Sullivan, 2005).

Studies on ethnicity, race and disability provide further evidence of the infusion of common sense views of 'ideal' careers with social identities. They first show that 'ideal', full-time, uninterrupted careers are mainly reserved for dominant groups, while disabled individuals and individuals from subordinate ethnic and racial groups are more likely to have career trajectories characterized by involuntary interruptions, downward mobility, or part-time employment (Barnes \& Mercer, 2005; Mong \& Roscigno, 2010; Schur, Kruse, Blasi, \& Blanck, 2009). Moreover, when they do have access to full-time and uninterrupted employment, studies argue that these individuals can still have more difficulties attaining subjective career success. Studies on ethnic minorities for example highlight how common sense views of 'ideal' careers are organized around the traditions of dominant racial and ethnic groups (e.g. the dominant cultural and religious calendar). This makes them less compatible with other cultural or religious traditions, 
Van Laer, Verbruggen \& Janssens

and sometimes hard to combine with cultural, non-work obligations of individuals with certain ethnic backgrounds (Janssens \& Zanoni, 2014; Kamenou, 2008). Disability studies argue these common sense views reflect the situation of able-bodied, healthy workers who are not afflicted by impairments or serious illnesses. As a result, disabled employees are, like women, often forced to choose between part-time careers with little opportunities for objective career success or full-time 'ideal' careers that can be difficult to sustain over time (Foster \& Wass, 2013; Harlan \& Robert, 1998). Finally, age studies highlight the existence of common sense views of the career steps an individual should have taken by a certain age, as well as the negative career effects of not following them. They further argue that, on the one hand, the common sense view exists that older individuals are no longer interested in 'ideal' careers. On the other hand, if they want to deviate from 'ideal' young careers to create a better balance between their identity and their work, this can threaten their further career opportunities (Kunze, Boehm, \& Bruch, 2013; Riach, 2007; Truxillo et al., 2015). Together, this leads us to the following proposition:

Proposition 3: Career boundaries involving labour market scripts affect the career success of different social identity groups to different degrees because common sense views of 'ideal' careers are infused with social identities.

Second, we propose that structural career boundaries involving labour market scripts are infused with social identities, as social identities are engrained the everyday workplace behaviour that employees are expected to display, thereby turning certain social identity groups into the standard for 'ideal' workplace conduct. Studies on race and ethnicity have long shown that informal organizational life is shaped by the dominant racial or ethnic groups' cultural norms, practices and rituals (e.g. their ways of 
Van Laer, Verbruggen \& Janssens

dressing, behaving, greeting) and that deviating from them can lead to exclusion. While assimilation to 'ideal' workplace conduct can increase individuals' chances of objective career success, this requires subordinate racial and ethnic groups to suppress elements of their identities, which, in turn, is associated negatively with subjective career success (Ely \& Thomas, 2001; Janssens \& Zanoni, 2014).

Disability studies similarly show how disabled employees can increase their chances of objective success by adhering to 'ideal' non-disabled behavioural scripts, which can for example involve hiding or downplaying their disability (McKinney \& Swartz, 2019; Schur et al., 2009). Studies on gender show how women, unlike men, often become confronted with a 'double bind' in terms of 'ideal' workplace conduct. This means that they risk less objective career success if the act too 'feminine' and risk being disliked if they act too 'masculine' (Acker, 2006). Finally, a similar discussion on 'ideal' workplace conduct can be found the literature on age. Given the societal and cultural value placed on it, youth tends to be the model for 'ideal' workplace conduct. Studies show that older employees - and especially older women - therefore experience pressure to adhere to 'young' scripts, hide signs of ageing, dress younger, and avoid topics that signal their 'real' age (Riach \& Kelly, 2013; Thomas et al., 2014). Together, this leads us to the following proposition:

Proposition 4: Career boundaries involving labour market scripts affect the career success of different social identity groups to different degrees because common sense views of 'ideal' workplace conduct are infused with social identities.

Table 1 provides a summary of the connections between common sense views and arguments in the literature on different social identities. 
INSERT TABLE 1 ABOUT HERE

\section{An analysis of the way OCM practices address career boundaries}

In the previous section, we developed propositions on the infusion of structural career boundaries with social identities, causing them to contribute to unequal career opportunities. A second aim of this article is to examine how different types of Organizational Career Management (OCM) practices address career boundaries and whether they can contribute to equal opportunities. This is important because, while the 'new career' discourse has placed much emphasis on individual career management, organizations continue to 'shape mobility patterns and the career development opportunities an individual can have' (De Vos, Dewettinck, \& Buyens, 2008, p. 157). One way they deliberately do so, is through OCM practices, or "those activities undertaken by the organization, in order to plan and manage the careers of its employees' (De Vos et al., 2008, p. 161) (Baruch, 2003; Baruch \& Peiperl, 2000; De Vos \& Cambré, 2017). Previous studies have discussed the different types of OCM practices and their potential positive effects on individuals' career development (Baruch, 2003; Baruch \& Peiperl, 2000; De Vos \& Cambré, 2017). However, it remains unclear whether they also lead to equal opportunities to share in the 'new career' discourse's promise of increased freedom to attain objective and subjective career success. We propose that different types of OCM practices address career boundaries in different ways. However, as long as common sense views of 'ideal' qualifications and labour market scripts are not changed, they can only maximize individuals' career opportunities within a constellation of structural career boundaries that privilege specific social identity groups, thereby not resulting in equal opportunities. 
Van Laer, Verbruggen \& Janssens

A first, and the most common, type of OCM practices (Baruch, 2003; Baruch \& Peiperl, 2000; De Vos et al., 2008; Greenhaus, Callanan, \& Godshalk, 2010) are those focused on developing qualifications and labour market behaviours. Examples are training, career counselling, career workshops, development centres, personal career planning, or mentoring programs. These practices target commonly identified individual-level boundaries (Gunz et al., 2007; Sullivan \& Baruch, 2009) linked to career actors' individual characteristics, attitudes, and deficits. On the one hand, these practices can help actors more closely match 'ideal' qualifications and labour market scripts. However, in doing so, they instil dominant common sense views in career actors rather than address the problem that these privilege certain groups and that not all career actors equally benefit from adopting them (Acker, 2006; Janssens \& Zanoni, 2014; Schur et al., 2009). On the other hand, these OCM practices can help career actors develop qualifications and labour market behaviours that are currently not considered 'ideal'. However, these are less likely to be rewarded with success as long as common sense views are not changed. This leads to the following proposition:

Proposition 5: OCM practices helping career actors develop qualifications and labour market behaviours address boundaries on an individual level, but will only result in equal opportunities if common sense views of 'ideal' qualifications and labour market scripts are changed.

A second common type of OCM practices focus on ensuring that career actors' qualifications and labour market behaviours are evaluated objectively by other actors. Examples of such practices (e.g. Baruch, 2003; Baruch \& Peiperl, 2000; De Vos et al., 2008; Greenhaus et al., 2010) are $360^{\circ}$ appraisals, tests for succession planning or assessment centres. These practices target commonly identified individual-level 
Van Laer, Verbruggen \& Janssens

boundaries (Baruch \& Vardi, 2016; Gunz et al., 2007), as they aim to ensure that the evaluation of career actors is not impacted by the individual biases and preferences of other actors. However, in doing so, these practices mainly ensure that actors are evaluated more objectively in relation to existing understandings of 'ideal' qualifications and labour market scripts rather than necessarily address the problem that these privilege certain social identity groups (Acker, 2006; Ely \& Thomas, 2001; Janssens \& Zanoni, 2014). These OCM practices will therefore only lead to equal opportunities if these common sense views are changed. This leads to the following proposition:

Proposition 6: OCM practices ensuring that qualifications and labour market behaviours are evaluated objectively address boundaries on an individual level, but will only result in equal opportunities if common sense views of 'ideal' qualifications and labour market scripts are changed.

A third, but less commonly identified, type of OCM practices focus on accommodating alternative qualifications and labour market behaviours. Examples are flexible work schedules and career paths, i-deals, phased retirement, reasonable accommodations, designated mentoring programs, targeted recruitment and quota systems (e.g. Baruch, 2003; Greenhaus et al., 2010). Unlike the previous two types, these practices address boundaries as structural-level problems. They do so by acknowledging common sense views of 'ideal' qualifications and labour market scripts that privilege certain social identity groups, and by accommodating alternative qualifications or labour market behaviours. While these practices have been important in improving the career opportunities of actors with specific social identities, studies on reasonable accommodations (e.g. Harlan \& Robert, 1998) and work-life policies (e.g. 
Van Laer, Verbruggen \& Janssens

Kossek et al., 2010) also show that the accommodated qualifications and labour market behaviours continue to be compared to 'ideal' qualifications and labour market scripts. These OCM practices will therefore only lead to equal opportunities if common sense views become changed. This leads to the following proposition:

Proposition 7: OCM practices accommodating alternative qualifications and labour market behaviours address boundaries on a structural level, but will only result in equal opportunities if common sense views of 'ideal' qualifications and labour market scripts are changed.

\section{Towards inclusive common sense views of qualifications and labour market scripts}

As the previous section showed, changing common sense views of 'ideal' qualifications and labour market scripts is crucial to challenge existing constellations of structural career boundaries infused with social identities and enable OCM practices to effectively contribute to equal opportunities. This idea echoes the arguments of Greenhaus and colleagues (2010), who discuss the importance of combining flexible working arrangements with organizational efforts to 'eliminate outdated assumptions' (p. 309) regarding the link between work and private life. Similar arguments on addressing inequality by rethinking common sense views can be found in the literature on gender (e.g. Ely \& Meyerson, 2010), age (e.g. Kunze et al., 2013), ethnicity/race (e.g. Ely \& Thomas, 2001) and disability (e.g. Schur et al., 2009). Despite this wide support, studies tend to be clearer on the importance of changing common sense views than on the way to do so (Ely \& Meyerson, 2010; Zanoni et al., 2010). Moreover, they often only focus on one aspect of structural boundaries (e.g. family-unfriendly career scripts) or on one social identity, rather than on developing common sense views that are inclusive of 
Van Laer, Verbruggen \& Janssens

different social identity groups and thereby challenge structural career boundaries facing different groups. Based on insights from the literature on diversity management and on social identity groups, we offer suggestions on what inclusive common sense views of qualifications and labour market scripts might look like, and propose that incorporating them in bundles of OCM practices enables these to effectively contribute to equal career opportunities.

\section{Inclusive common sense views of qualifications}

We argue that inclusive common sense views of qualifications are based on the idea that different types of qualifications are valuable, and should be seen as important sources for learning, developing new ideas, and creativity (Ely \& Meyerson, 2010; Ely \& Thomas, 2001; Janssens \& Zanoni, 2014). Bundles of OCM practices incorporating such a view therefore treat different qualifications as important resources to be nurtured, rewarded and utilized.

Incorporating this view in OCM practices aimed at developing career actors' qualifications means not focusing on the 'right' qualifications but rather on the ability of career actors to leverage their existing qualifications. Their goal would thereby be to help career actors discover, nurture and realize the potential of their unique qualifications, and stimulate the exchange of different qualifications among career actors (Ely \& Meyerson, 2010; Ely \& Thomas, 2001; Truxillo et al., 2015). Crucially, such practices will only lead to equal opportunities if they are combined with OCM practices focused on ensuring objective evaluations incorporating this same inclusive view of qualifications and rewarding them with career success. Examples are evaluations (e.g. for selection or promotion) which do not look for a predetermined set of 'ideal' qualifications, but rather judge individuals on both a threshold of minimum required qualifications reflecting absolutely essential job requirements, and their ability 
Van Laer, Verbruggen \& Janssens

to diversify (the qualifications of) a team. Another example is the combination of individual evaluations (e.g. on employees' willingness to learn and exchange knowledge) with team-based evaluations that stimulate team members to optimally use the available qualifications to achieve team goals (Ely \& Meyerson, 2010; Janssens \& Zanoni, 2014; Roos \& Zanoni, 2016). However, this inclusive approach is only possible if it is embedded in a bundle with OCM practices accommodating alternative qualifications, for example through adapting jobs to individuals and shifting tasks between jobs within a team. To ensure that these accommodations are not seen as deviations from a norm, and are not solely negotiable by employees with significant (bargaining) power, which is often the case for i-deals or job crafting (Berg, Wrzesniewski, \& Dutton, 2010; Rousseau, 2005), they would need to be made a normal aspect of organizational functioning and truly be made available to all organizational members (Janssens \& Zanoni, 2014; Kulkarni, 2016; Kunze et al., 2013; Roos \& Zanoni, 2016). Together, this leads us to the following proposition:

Proposition 8: Bundles of OCM practices incorporating inclusive common sense views of qualifications will effectively contribute to equal opportunities because they challenge structural career boundaries infused with social identities.

\section{Inclusive common sense views of labour market scripts}

We argue that inclusive common sense views of labour market scripts are based on the idea that different types of labour market scripts are normal, and should be seen as important sources for subjective success and the sustainability of careers (Janssens \& Zanoni, 2014; Kossek et al., 2010; Mainiero \& Sullivan, 2005). Bundles of OCM 
Van Laer, Verbruggen \& Janssens

practices incorporating such a view therefore treat different labour market scripts as equally valid options to be developed, valued and supported.

Incorporating this view in OCM practices aimed at developing career actors' labour market behaviour means not focusing on the 'right' labour market behaviour but on helping career actors discover their own needs, incorporate them in their career decisions and workplace conduct, and strengthen their ability to optimally manage and negotiate their availability. However, this only leads to more equal opportunities if this inclusive view is also incorporated in OCM practices focused on ensuring objective evaluations. Examples of such practices are evaluations that equally value different career trajectories, do not punish career breaks or working part-time, and focus on career actors' effective use of the afforded flexibility (Mainiero \& Sullivan, 2005). This inclusive approach is only possible if it is combined with OCM practices accommodating different labour market behaviour and allowing the adaptation of availabilities and career trajectories to all types of individual (family, health, cultural,...) needs. This can involve using internal mobility to temporarily adapt employees' careers to their needs, allowing career actors maximum freedom to organize their working day, and providing clear career off- and on-ramps. It is again important to make this policy a normal aspect of organizational functioning and available to all employees, regardless of their hierarchical level or social identities (Kossek et al., 2010; Kulkarni, 2016; Mainiero \& Sullivan, 2005; Truxillo et al., 2015). Together, this leads us to the following proposition:

Proposition 9: Bundles of OCM practices incorporating inclusive common sense views of labour market scripts will effectively contribute to equal opportunities because they challenge structural career boundaries infused with social identities. 
Van Laer, Verbruggen \& Janssens

\section{Conclusion and research agenda}

Bringing together the separate literature streams on 'new careers', career boundaries and OCM, on four social identities, and on diversity management, this article offers a novel analysis of the way structural boundaries impact the careers of different social identity groups, the way different types of OCM practices address career boundaries, and the way they can contribute to equal opportunities. To conclude, we suggest a research agenda for studies on careers, career boundaries, and OCM practices to quantitatively test and qualitatively examine the propositions developed throughout this paper. We particularly highlight three areas of attention: the career effects of common sense views, the career effects of OCM practices, and the role of context in the emergence of common sense views and their incorporation in OCM practices. Table 2 gives an overview of potential qualitative and quantitative questions in these three areas, which will be further discussed below.

\section{INSERT TABLE 2 ABOUT HERE}

A first area of attention is, in line with propositions 1-4, further examining whether common sense views affect people's career success differently depending on their social identity. Here, research could, for example, examine how the relationship between specific qualifications or (adherence to) labour market scripts and indicators of objective and subjective career is different for employees from different social identity groups. While we have some insight in the negative effects of common sense views on careers, more research is needed in their potentially conflicting positive and negative, or 
Van Laer, Verbruggen \& Janssens

short-term and long-term effects on different indicators of objective and subjective career success. Furthermore, researchers could study how individual differences affect the way individuals manoeuvre structural boundaries (e.g. acquiring specific competencies or entering certain professions), and whether the relationship with different indicators of career success is affected by social identities.

A second area of attention is, in line with propositions 5-9, the impact of different types of OCM practices. Here, researchers could explore OCM practices as antecedents of (evaluations of) qualifications and labour market behaviour and of different indicators of career success, and how these relationships are moderated by social identities. Our propositions suggest that the relationship between OCM practices and career success will be less strong for some social identity groups than for others. Additionally, it is important to not only focus on the absence or presence of single OCM practices, but rather to explore the effects of different bundles of OCM practices, as well as of OCM practices incorporating different views of qualifications and labour market scripts.

Third, related to all propositions, more research is needed on the role of the context in the existence of different common sense views and in their incorporation in (bundles of) OCM practices. Attention for social identities would involve focusing on the influence of the representation and position of different social identity groups within labour markets, organizational hierarchies, customer bases, or sectors. An exploration of new sectors such as the start-up and tech sector would give the most direct insight into the emergence of structural career boundaries. Another important factor to consider is the national context, as much of the literature referenced in this text originates from 'Western' countries. Finally, attention should be paid to the contextual elements that 
Van Laer, Verbruggen \& Janssens

influence the incorporation of different common sense views in different types of OCM practices.

Going beyond this article, future research should also include attention for other social identities (e.g. sexual identities), as well as for intersections between, and relevant sub-identities (e.g. refugees or skilled migrants) of, social identities. In this way, this research agenda can help us ensure that all individuals can share in the promise of the 'new career' discourse and gain more freedom to attain both objective and subjective career success, regardless of their social identities.

\section{References}

Acker, J. (2006). Inequality regimes: Gender, class, and race in organizations. Gender and Society, 20, 441-464.

Arnold, J., \& Cohen, L. (2008). The psychology of careers in industrial and organizational settings: A critical but appreciative analysis. In G.P. Hodgkinson \& J.K. Ford (Eds.), International Review of Industrial and Organizational Psychology Volume 23 (pp. 1-44). Chichester: John Wiley \& Sons.

Arthur, M.B. (2014). The boundaryless career at 20: Where do we stand, and where can we go? Career Development International, 19, 627-640.

Arthur, M.B., \& Rousseau, D.M. (1996). Introduction: The boundaryless career as a new employment principle. In M.B. Arthur \& D.M. Rousseau (Eds.), The boundaryless career (pp. 3-20). New York: Oxford University Press.

Barnes, B., \& Mercer, G. (2005). Disability, work, and welfare: Challenging the social exclusion of disabled people. Work, Employment and Society, 19, 527-545.

Baruch, Y. (2003). Career systems in transition: A normative model for organizational career practices. Personnel Review, 32, 231-251.

Baruch, Y., \& Peiperl, M. (2000). Career management practices: An empirical survey and implications. Human Resource Management, 39, 347-366.

Baruch, Y., \& Vardi, Y. (2016). A fresh look at the dark side of contemporary careers: Toward a realistic discourse. British Journal of Management, 27, 355-372. 
Berg, J.M., Wrzesniewski, A., \& Dutton, J.E. (2010). Perceiving and responding to challenges in job crafting at different ranks: When proactivity requires adaptivity. Journal of Organizational Behavior, 31, 158-186.

Dany, F., Louvel, S., \& Valette, A. (2011). Academic careers: The limits of the 'boundaryless approach' and the power of promotion scripts. Human Relations, 64, 971-996.

De Vos, A., \& Cambré, B. (2017). Career Management in High-Performing Organizations: A Set-Theoretic Approach. Human Resource Management, 56, $501-518$.

De Vos, A., Dewettinck, K., \& Buyens, D. (2008). To move or not to move? The relationship between career management and preferred career moves. Employee Relations, 30, 156-175.

Ely, R.J., \& Meyerson, D.E. (2010). An organizational approach to undoing gender: The unlikely case of offshore oil platforms. Research in Organizational Behavior, 30, 3-34.

Ely, R.J., \& Thomas, D.A. (2001). Cultural diversity at work: The effects of diversity perspectives on work group processes and outcomes. Administrative Science Quarterly, 46, 229-273.

Foster, D., \& Wass, V. (2013). Disability in the labour market: An exploration of concepts of the ideal worker and organisational fit that disadvantage employees with impairments. Sociology, 47, 705-721.

Garbe, E., \& Duberley, J. (2019). How careers change: understanding the role of structure and agency in career change. The case of the humanitarian sector. The International Journal of Human Resource Management. Advanced online publication. Doi:10.1080/09585192.2019.1588345

Greenhaus, J.H., Callanan, G.A., \& Godshalk, V.M. (2010). Career management. Thousand Oaks, CA: SAGE Publications.

Gunz, H., Peiperl, M., \& Tzabbar, D. (2007). Boundaries in the study of career. In H. Gunz \& M. Peiperl (Eds.), Handbook of career studies (pp. 471-494). Thousand Oaks, CA: SAGE Publications.

Hakak, L.T., \& Al Ariss, A. (2013). Vulnerable work and international migrants: A relational human resource management perspective. The International Journal of Human Resource Management, 24, 4116-4131. 
Van Laer, Verbruggen \& Janssens

Hall, D.T. (1996). Protean careers of the 21 st century. The Academy of Management Executive, 10(4), 8-16.

Hall, D.T. (2004). The protean career: A quarter-century journey. Journal of Vocational Behavior, 65, 1-13.

Harlan, S.L., \& Robert, P.M. (1998). The social construction of disability in organizations: Why employers resist reasonable accommodation. Work and Occupations, 25, 397-435.

Iellatchitch, A., Mayrhofer, W., \& Meyer, M. (2003). Career fields: a small step towards a grand career theory? The International Journal of Human Resource Management, 14, 728-750.

Inkson, K, Gunz, H., Ganesh, S., \& Roper, J. (2012). Boundaryless careers: Bringing back boundaries. Organization Studies, 33, 323-340.

Ituma, A., \& Simpson, R. (2009). The 'boundaryless' career and career boundaries: Applying an institutionalist perspective to ICT workers in the context of Nigeria. Human Relations, 62, 727-761.

Janssens, M., \& Zanoni P. (2014). Alternative diversity management: Organizational practices fostering ethnic equality at work? Scandinavian Journal of Management, 30, 317-331.

Kamenou, N. (2008). Reconsidering work-life balance debates: Challenging limited understanding of the 'life' component in the context of ethnic minority women's experiences. British Journal of Management, 19, S99-S109.

Kaufman, R. (2002). Assessing alternative perspectives on race and sex employment segregation. American Sociological Review, 67, 547-572.

Kossek, E.E., Lewis, S., \& Hammer, L. (2010). Work-life initiatives and organizational change: Overcoming mixed messages to move from the margin to the mainstream. Human Relations, 63, 3-19.

Kulkarni, M. (2016). Organizational career development initiatives for employees with a disability. The International Journal of Human Resource Management, 27, $1662-1679$.

Kunze, F., Boehm, S., \& Bruch, H. (2013). Organizational performance consequences of age diversity: Inspecting the role of diversity-friendly HR policies and top managers' negative age stereotypes. Journal of Management Studies, 50, 413442. 
Laudel, G., Bielick, J., \& Gläser, J. (2019) 'Ultimately the question always is: "What do I have to do to do it right?"' Scripts as explanatory factors of career decisions. Human Relations, 72, 932-961.

Lindsay, S., Adams, T., Sanford, R., McDougall, C., Kingsnorth, S., \& Menna-Dack, D. (2014). Employers' and employment counselors' perceptions of desirable skills for entry-level positions for adolescents: How does it differ for youth with disabilities? Disability \& Society, 29, 953-967.

Mainiero, L.A., \& Sullivan, S.E. (2005). Kaleidoscope Careers: An Alternate Explanation for the "Opt-out" Revolution. The Academy of Management Executive, 19(1), 106-123.

McKinney, E.L. \& Swartz, L. (2019). Employment integration barriers: experiences of people with disabilities. The International Journal of Human Resource Management. Advanced online publication doi:10.1080/09585192.2019.1579749

Mong, S.N., \& Roscigno, V.J. (2010). African American men and the experience of employment discrimination. Qualitative Sociology, 33, 1-21.

Moss, P., \& Tilly, C. (1996). "Soft” skills and race: An investigation of black men's employment problems. Work and Occupations, 23, 252-276.

Peterson, H. (2007). Gendered work ideals in Swedish IT firms: Valued and not valued workers. Gender, Work and Organization, 14, 333-348.

Riach, K. (2007). 'Othering' older worker identity in recruitment. Human Relations, 60, 1701-1726.

Riach, K., \& Kelly, S. (2013). The need for fresh blood: Understanding organizational age inequality through a vampiric lens. Organization, 22, 287-305.

Rousseau, D.M. (2005). I-deals: Idiosyncratic deals employees bargain for themselves. Armonk, N.Y.: M.E. Sharpe

Roos, H., \& Zanoni, P. (2016). Disrupting gendered dichotomies: Gender equality in a high-tech Belgian company. In P.M. Flynn, K. Haynes \& M.A. Kilgour (Eds.), Overcoming challenges to gender equality in the workplace (pp. 8-20). Abingdon: Routledge.

Schur, L., Kruse, D., Blasi, J., \& Blanck, P. (2009). Is disability disabling in all workplaces? Workplace disparities and corporate culture. Industrial Relations, $48,381-410$. 
Van Laer, Verbruggen \& Janssens

Sullivan, S., \& Y. Baruch (2009). Advances in career theory and research: A critical review and agenda for future exploration. Journal of Management, 35, 15421571.

Thomas, R., Hardy, C., Cutcher, L., \& Ainsworth, S. (2014). What's age got to do with it? On the critical analysis of age and organizations. Organization Studies, 35, $1569-15$

Truxillo, D.M., Cadiz, D.M., \& Hammer, L.B. (2015). Supporting the aging workforce: A review and recommendations for workplace intervention research. Annual Review of Organizational Psychology and Organizational Behavior, 2, 351381.

Zanoni, P., Janssens, M., Benschop, Y., \& Nkomo, S. (2010). Unpacking diversity, grasping inequality: Rethinking difference through critical perspectives. Organization, 17, 9-29. 
Van Laer, Verbruggen \& Janssens

Table 1. Common sense views and social identities

\begin{tabular}{|c|c|c|c|c|}
\hline & \multicolumn{2}{|c|}{ Structural boundaries involving qualifications } & \multicolumn{2}{|c|}{ Structural boundaries involving labour market scripts } \\
\hline & 'Ideal' competencies & 'Ideal' job holders & 'Ideal' careers & 'Ideal' workplace conduct \\
\hline Gender & $\begin{array}{l}\text { 'Ideal' competencies reflect } \\
\text { (ascribed) attributes of men. }\end{array}$ & $\begin{array}{l}\text { Women as 'ideal' job holders } \\
\text { of lower-status jobs. }\end{array}$ & $\begin{array}{l}\text { 'Ideal' careers reflect a 'male } \\
\text { breadwinner model'. }\end{array}$ & $\begin{array}{l}\text { Masculinity as 'ideal' } \\
\text { conduct for objective career } \\
\text { success. }\end{array}$ \\
\hline $\begin{array}{l}\text { Race / } \\
\text { ethnicity }\end{array}$ & $\begin{array}{l}\text { 'Ideal' hard (e.g. degrees) and } \\
\text { soft (e.g. communication) } \\
\text { skills reflect dominant racial } \\
\text { and ethnic groups. }\end{array}$ & $\begin{array}{l}\text { Subordinate racial and ethnic } \\
\text { groups as 'ideal' holders of } \\
\text { low-status jobs. }\end{array}$ & $\begin{array}{l}\text { Involuntary 'non-ideal' } \\
\text { careers. } \\
\text { 'Ideal' careers reflect } \\
\text { traditions of dominant racial } \\
\text { and ethnic groups. }\end{array}$ & $\begin{array}{l}\text { Pressures to assimilate to } \\
\text { 'ideal' conduct reflecting } \\
\text { dominant racial/ethnic } \\
\text { cultural norms. }\end{array}$ \\
\hline Disability & $\begin{array}{l}\text { 'Ideal' competencies reflect } \\
\text { non-disabled individuals' } \\
\text { (ascribed) attributes. }\end{array}$ & $\begin{array}{l}\text { Disabled individuals as 'less } \\
\text { ideal' holders of jobs in the } \\
\text { 'regular' economy. }\end{array}$ & $\begin{array}{l}\text { Involuntary 'non-ideal' } \\
\text { careers. } \\
\text { 'Ideal' careers reflect non- } \\
\text { disabled individuals. }\end{array}$ & $\begin{array}{l}\text { Pressures to hide or } \\
\text { downplay disability to } \\
\text { conform to 'ideal' non- } \\
\text { disabled workplace conduct. }\end{array}$ \\
\hline Age & $\begin{array}{l}\text { 'Ideal' 'new career' } \\
\text { competencies reflect } \\
\text { attributes ascribed to young } \\
\text { individuals. }\end{array}$ & $\begin{array}{l}\text { Age of 'ideal' holder depends } \\
\text { on job. } \\
\text { Jobs in the 'new economy' } \\
\text { connected to youth. }\end{array}$ & $\begin{array}{l}\text { Timetables for 'ideal' career } \\
\text { progression. } \\
\text { Older individuals seen as } \\
\text { uninterested in 'ideal' careers. }\end{array}$ & $\begin{array}{l}\text { Youthfulness as 'ideal' } \\
\text { workplace conduct. }\end{array}$ \\
\hline
\end{tabular}


Table 2. Suggestions for research

\begin{tabular}{|c|c|c|c|c|}
\hline & \multicolumn{2}{|c|}{ Qualitative approach } & \multicolumn{2}{|c|}{ Quantitative approach } \\
\hline & Potential research questions & Potential methods & Potential research questions & Potential methods \\
\hline $\begin{array}{l}\text { Effects of } \\
\text { common sense } \\
\text { views }\end{array}$ & $\begin{array}{l}\text { How do individuals with } \\
\text { different social identities } \\
\text { experience the effects of specific } \\
\text { common sense views? } \\
\text { Which strategies do individuals } \\
\text { with different social identities } \\
\text { deploy to navigate boundaries } \\
\text { and attain career success? }\end{array}$ & $\begin{array}{l}\text { Interviews with } \\
\text { career actors, diary } \\
\text { studies. }\end{array}$ & $\begin{array}{l}\text { Is the relationship between } \\
\text { competencies and indicators of } \\
\text { career success moderated by } \\
\text { individuals' social identity? } \\
\text { Is adherence to labour market } \\
\text { scripts related differently with } \\
\text { indicators of career success } \\
\text { depending on one's social } \\
\text { identity? }\end{array}$ & $\begin{array}{l}\text { Multiple wave, } \\
\text { multilevel and/or } \\
\text { multisource surveys }\end{array}$ \\
\hline Effects of OCM & $\begin{array}{l}\text { How do individuals with } \\
\text { different social identities } \\
\text { experience OCM practices and } \\
\text { their effects on their careers? } \\
\text { How can OCM practices be } \\
\text { designed in a way that } \\
\text { maximizes their effects on the }\end{array}$ & $\begin{array}{l}\text { In-depth case studies. } \\
\text { Interviews with } \\
\text { career practitioners, } \\
\text { gatekeepers or career } \\
\text { actors. }\end{array}$ & $\begin{array}{l}\text { Are different types of OCM } \\
\text { practices related with } \\
\text { differences in career success } \\
\text { depending on one's social } \\
\text { identity? } \\
\text { Does the relationship between } \\
\text { OCM practices and the career } \\
\text { success of different social }\end{array}$ & $\begin{array}{l}\text { Organizational-level } \\
\text { data collections on } \\
\text { OCM practices. } \\
\text { Employee surveys. }\end{array}$ \\
\hline
\end{tabular}


career success of individuals

with different social identities?

Role of context Why are particular types of career considered normal in a context and how is this impacted by the representation and position of different social identity groups?

How does the representation and position of different social identity groups impact the design of OCM practices? identity groups depend on their

approach to qualifications?

In-depth case studies. Are the same qualifications

Interviews with

valued differently across

contexts and how is this

Multilevel survey

research.

Correspondence tests gatekeepers or career actors.

moderated by the representation and position of different social identity groups?

Analysis of

documents (e.g. job postings).

Do labour market scripts differ between organizations depending on the representation and position of different social identity groups? 